\title{
The U.S. Financial Crisis and its Impact on the Global Oil Market
}

\section{MOUSAVI Hamed ${ }^{20}$}

\begin{abstract}
Oil prices fell sharply with the US financial crisis, going below \$35 a barrel before going back up to the current $\$ 77$ per barrel. This article attempts to identify the causes behind the rise of oil prices in the last two decades, the impact of the US financial crisis on the price of oil followed by an analysis on the future of oil prices. It is argued that an increase in demand, lagging supply, low spare capacity and the inelasticity of both supply and demand, sepculation and finally depraciation in the value of the Dollar have driven up prices in the past two decades. Subsequently, the 2008 US financial crisis led to the slow down of the global economy and as a result oil demand shrunk, bringing oil prices to under 35 dollars. While the global economic crisis seriously curtailed oil demand, however this was a short term decline. The US economy slowly began to recover starting in 2009, leading to recoveries elsewhere around the world. This brought oil prices to over 70 dollars today. Futhermore it can be expected that since the fundamental reasons behind rising oil prices, being demand and supply, are still valid, thus in the long run oil prices will increase to pre-crisis levels of over a hundred dollars.

Keywords: Global Oil Market, US Financial Crisis, Oil Prices, Global Economy, US Economy

JEL: M30

UDC: $339.13: 553.982(73)$

338.124.4

COBISS.SR-ID 265410060

\section{Introduction}

Recent years have seen a sharp rise in the price of oil. While the price of oil has seen many fluctuations in past decades, most of them have been short term fluctuations due to war, political instability and other reasons. The consistent price increase from $\$ 20$ at the start of the twenty first century to the high point of $\$ 147$ in summer 2008 (Kebede, 2008), toward its current price of $\$ 77$ has been unlike previous trends. This is apparent in the graph shown below.
\end{abstract}

\footnotetext{
${ }^{20}$ Faculty of Law and Political Science, University of Tehran,e-mail: hamedmousavi@ut.ac.ir.
} 


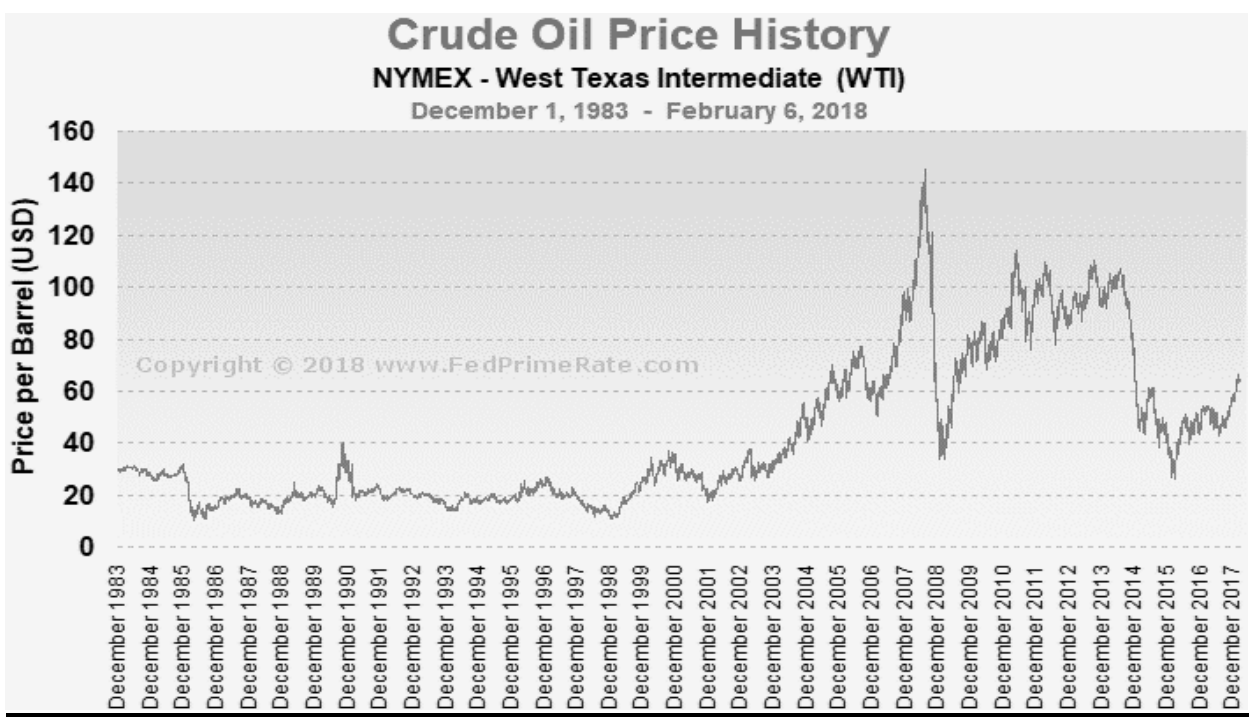

Fig. 1. World Oil Prices from 1983 to 2018

Source: Federal Prime Rate, 2018

Oil prices fell sharply with the global financial crisis in September 2008, going below $\$ 35$ a barrel (CNN, 2008), before going back up, to the current $\$ 77$ per barrel. This article attempts to identify the causes behind the rise of oil prices in the last two decades, the impact of the US financial crisis on the price of oil followed by an analysis on the future of oil prices.

\section{Forces Driving Up Prices in the Past Two Decades}

\section{Increase in Demand}

The demand for Oil in the past 30 years has been steadily rising. The pace of this rise however has increased since the start of the new century. Since then, oil demand rose by an average of $1.8 \%$ annually (Interim Report on Crude Oil, 2008) before diving after the 2008 financial crisis and then beginning to recover starting in 2009. There are various reasons for the rise in the demand for oil but the most important one is the growth of the world economy and subsequently the added need for energy resources to sustain this growth. A large part of this growth has been in non-OECD countries, especially China, India and countries of the Middle East. In the past couple of years where the price of oil has seen a substantial increase, the role of developing countries in the growth of demand for oil has been substantial. As apparent in graph 2, world GDP has seen a growth rate of around 2 to 4 percent in the past three decades. 


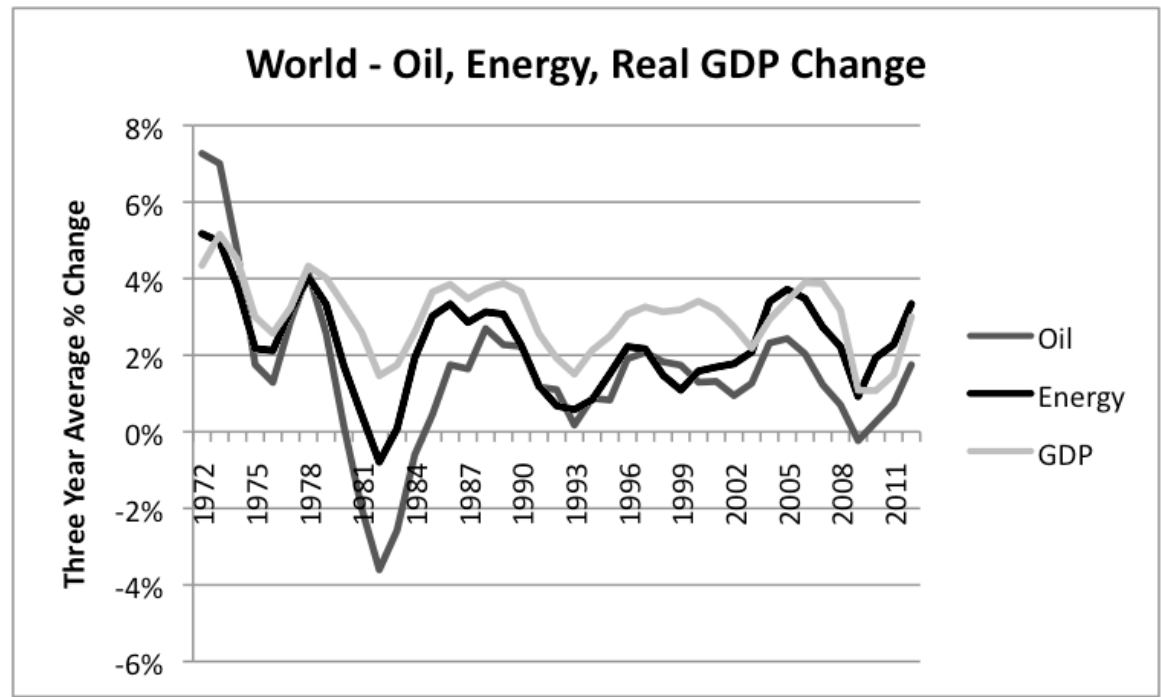

Fig. 2. Growth of World GDP and Oil Production

Source: Our Finite World (2013). Ten Reasons Why High Oil Prices are a Problem

As indicated earlier, China, India and the Middle East which are the fastest growing economies of the world, making up a large share of the growth in oil demand. This has especially been the case in the past years, where these economies have accounted for nearly two thirds of the growth in oil demand. The growth in demand by China alone has been over 40 percent from 2006 to 2011 as apparent in graph 3.

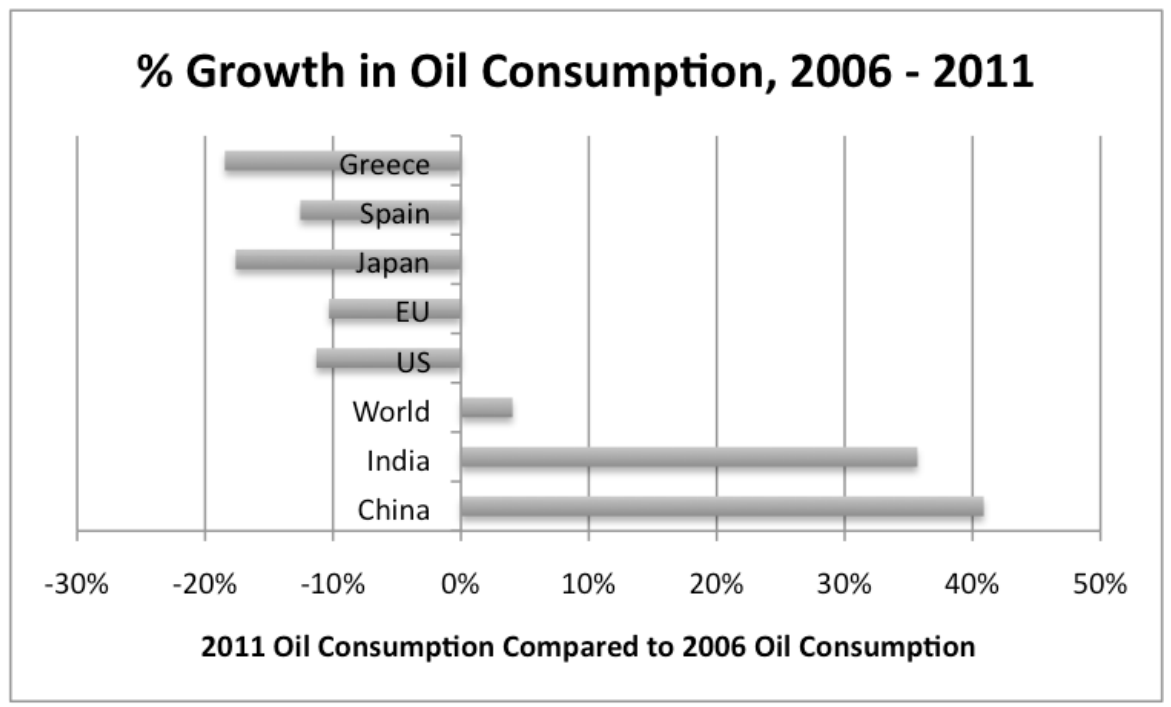

Fig. 3. Growth in Oil Consumption, 2006-2011

Source: Our Finite World (2013). Ten Reasons Why High Oil Prices are a Problem

The rise in demand of China, India and the Middle East have more than made up for the decrease in demand of the US, EU and Greece. Furthermore the International Energy Agency predicts that Chinese and Indian demand for oil will grow even fruther. The Agency predicts 
that Indian per capita oil consumption will rise from 1.2 barrels per year in 2017 to 1.5 barrels per year by 2022, while China's will rise from the 3 barrels per capita per year in 2017 to 3.5 by 2022 (International Energy Agency, 2017).

A large part of the increase in demand for oil in both OECD and non OECD countries has been the increase in the number of cars people use (The rise and fall in oil prices, 2008). In non OECD countries where the standard of living has risen substantially due to consistent economic growth, this is even more true. In some of these countries, the price of fuel is subsidized, reducing its price and subsequently increasing demand (Interim Report on Crude Oil, 2008).

Subsidizing fuel in these developing countries has also encouraged people to use less energy efficient cars and less incentive for manufacturers to design and produce energy efficient vehicles. Thus the share of the transportation sector in the consumption of oil in the past two decades has increased and is expected to increase even further in the future. According to the International Energy Agency (IEA), the share of the transport sector in total oil demand has risen from $35 \%$ in 1980 to $47 \%$ in 2005 , and is projected to rise further to $52 \%$ by 2030 (World Oil Outlook, 2008). Graph 4 illustrate this fact. As apparent in the graph, in OECD countries, if we do not take into account the increase demand of oil in the transportation sector, then actually the demand for oil has decreased. In non OECD countries however, the demand in both the transportation sector and the non-transportation sector has increased.

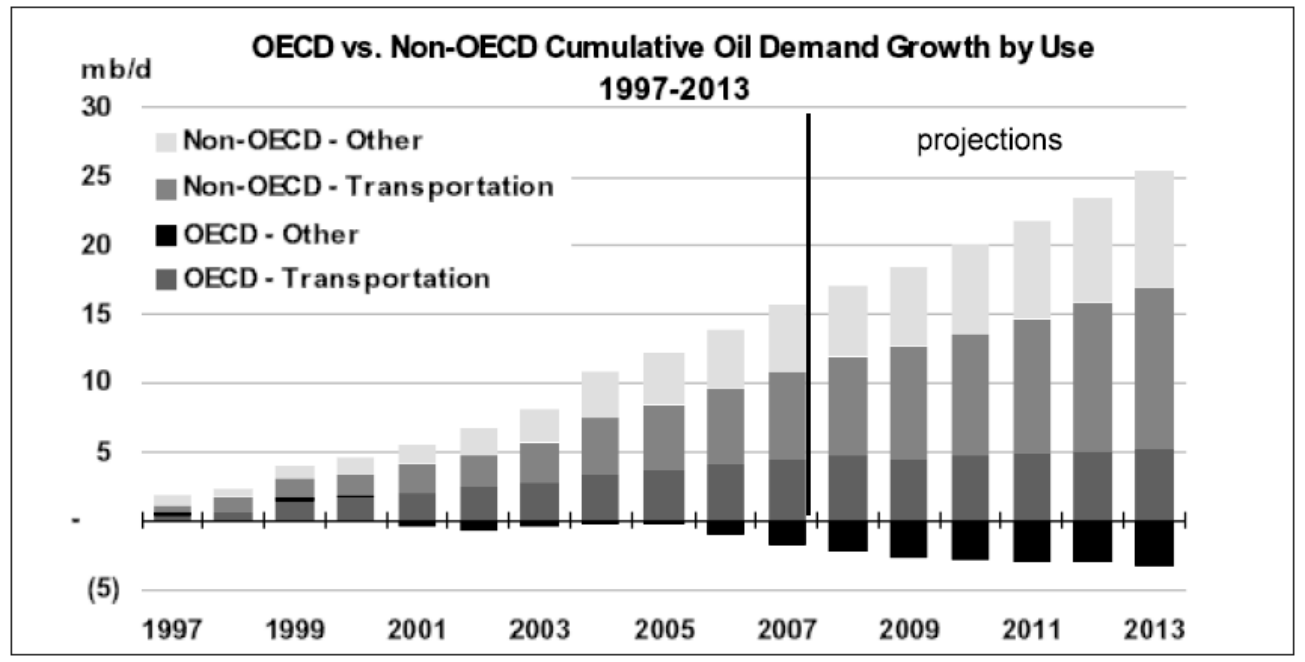

Fig. 4. OECD vs Non-OECD Cumulative Oil Demand Growth

Source: Medium-term Oil Market Report, International Energy Agency, 2008. Please note that the graph does not consider the decline in oil demand due to the global financial crisis.

\section{Lagging Supply}

Although the supply of oil has increased in the past twenty years, however the rise in supply has been unable to match the rise in demand. For example, although OPEC has been able to increase its production of oil from about 30.5 thousand barrels per day in January 2005 to nearly 33 thousand barrels per day in January 2018 (Peak Oil Barrel, 2018), the increase has been marginal. There are various reasons for the lag in the supply of oil. The most important of which is the lack of investment in the 1980s and 1990s in the oil industry. The very low prices of oil in the $80 \mathrm{~s}$ and $90 \mathrm{~s}$ had a significant impact in decreasing investment in the oil industry including in research and development. Low oil prices also meant that many oil fields with high costs of exploration and extraction were not exploited, since the production cost 
would exceed the price of oil at the time. With the sharp increase in prices since 2003, investment has also increased, however in this industry it takes a rather long time for investments to bear fruit, meaning that oil supply, like oil demand, is inelastic in the short term, which means that supply cannot be increased in the short run as the prices go up. This issue will be discussed in detail later in the article. Thus the oil industry was unprepared for the unexpected economic growth of the world and subsequently could not meet the world's increasing energy demands. In effect part of the high prices of the past two decades have been due to the low prices of the 80s and 90s (World Oil Outlook, 2008).

The following graph illustrates the world's supply. As apparent in the graph from 2006 to 2016, the world's oil supply increase slightly more than ten percent.

This tightening of the oil market in which the supply struggles to keep up with the demand is an essential element in the rise of oil prices. It is also why many buyers are worried about the future supply of oil which increases the prices even further. Figure 5: World Oil Supply from 1991 to 2016 (in million barrels per day)

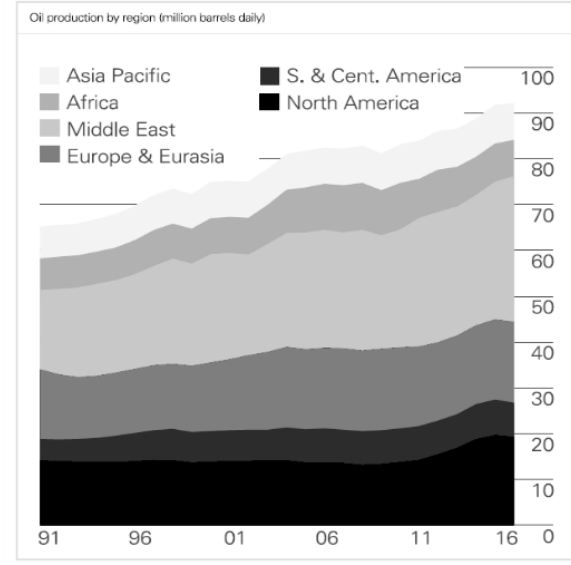

Fig. 5. World Oil Supply from 1991 to 2016 (in million barrels per day)

Source: British Petroleum (2018). Oil Production.

\section{Low spare capacity and the Inelasticity of both supply and demand}

Apart from the long time it takes investment in the oil industry to increase supply, the current excess concentrated capacity is also rather low. World spare oil capacity, is the excess amount of oil that can be produced in a short period of time. Most of the world's spare capacity is in Saudi Arabia. That is why Saudi Arabia has been able to offset, to some extent, the price increases in the past three decades, by increasing its production of oil in a short period of time, something that most other producers are incapable of. However in recent years, due to the high demand and subsequently higher supply of oil, spare capacity has dropped significantly. For example in the fourth quarter of 2017, OPEC's spare oil capacity was only 2.1 million barrels (US Energy Information Administration, 2018), which is around 2 percent of global consumption, compared to an average of 3.9 million barrels per day for the 1996-2003 period (Interim Report on Crude Oil, 2008). This means that the market cannot rely on oil producers to offset demand increases as well as offset supply disruptions such as wars and even perceived supply disruptions like geopolitical uncertainty, etc. This creates panic in the oil market in case of even small disruptions in the supply of oil. Low excess production capacity plus low inventories (stored oil) as well as the long lead time for investment discussed earlier, makes the supply of oil inelastic, meaning that the supply of oil cannot be increased substantially in the short run in response to price increases. The demand for oil is also inelastic, meaning that 
an increase in oil prices, decreases oil demand only slightly. This is due to fact that there are currently very few practical alternatives to oil, making it irreplaceable. Also oil is a key component for the function of many industries as well being needed for transportation fuels.

The inelasticity of supply and demand means, that when the equilibrium of supply and demand is lost, it takes a large price increase to reach a new equilibrium, since both the supply and the demand of oil are not very responsive to price changes. This is a critical factor in driving up oil prices in the world (The rise and fall in oil prices, 2008).

\section{Sepculation}

The increase in the so called "paper barrels traded" commonly referred to as speculation in the oil market, has also been an important factor in driving up prices. For example in The New York Mercantile Exchange (NYMEX), the world's largest physical commodity futures exchange, the number of paper barrels traded for each physical barrel has increased to 18 , up from 6 in 2003.

This constitutes a $300 \%$ increase in the number of trades for each physical barrel. There are a number of reasons for this increase (World Oil Outlook, 2008).

One obvious reason has been the continual increase in oil prices since 2003, making the trade very lucrative for many investors. Thus many investors including large financial institutions, hedge funds and foundations entered the oil trade market to make large profits.

Another reason for this speculative behavior is the issue of supply lagging demand and the low spare capacity discussed earlier. This has made many consumers as well traders and investors to come to the conclusion that in the future, the supply and demand of the oil market will get even tighter which will result in more price increases. Thus the market expectation during the past couple of years has been that the price of oil will be higher in the future. This obviously results in a mindset which believes it is better to buy now than in the future. Many of these purchases are for future deliveries.

The true impact of these speculative trade practices in driving up oil prices is disputed however. An interim report by the US Interagency Task Force on Commodity Markets in July 2008 , largely focusing on this specific issue, for example came to the conclusion that while this speculative activity has played a role in driving up prices however the main reason behind price increases has been due to fundamental supply and demand factors, with speculative activity having no systematic role in price increases (Interim Report on Crude Oil, 2008).

Speculative activity in the oil market has largely vanished since the start of the global financial crisis; this issue will be discussed in the later parts of the article.

\section{Depraciation in the value of the Dollar}

Another factor that has impacted oil prices has been the value of the US dollar.

Since oil is traded in US dollars internationally, the value of the US dollar plays an important role on the price of oil. The US dollar has depreciated in value significantly from 2002. This has made the price of oil more expensive, as each dollar is worth less than what it was worth before. The value of the US dollar versus the Euro has declined from 1.075 in January 2001 to 0.802 in January 2018 (Poundsterlinglive, 2018).

\section{The US Financial Crisis and It's Affect on the Oil Market}

In the several years before the global financial crisis of September 2008, with the perception that the US economy was doing well, with interest rates at all-time lows and the housing market booming, the US financial sector sensed that the economy was booming and that a lot of money could be made. Thus, they started giving loans for house purchase to people who under normal circumstances would not qualify for a loan. These individuals were people 
that did not have the appropriate income level, credit history, and employment status as well as risky individuals like illegal immigrants. The practice which is called 'Subprime Lending' had become so popular that by March 2007 the value of subprime mortgages in the United States was estimated to be around \$1.3 trillion (MSNBC, 2007).

By 2006, as interest rates started to rise and home prices started to decline the situation for many borrowers started to deteriorate. Many subprime borrowers could not afford to pay their mortgage payments on time. By this time the lenders, the financial institutions, started to get a sense of the declining house markets and slowly stopped their previous recklessly activity of giving easy loans. This made it very difficult for the subprime borrowers now in trouble to refinance their homes, which had already started to decline in value. This resulted in a dramatic increase in the number of foreclosures. During 2007, nearly 1.3 million U.S. housing properties were subject to foreclosure activity, up 79\% from 2006 (RealtyTrac, 2008). The decline in house prices along with home owners unable to pay their monthly instalments meant huge losses for the financial sector. This deterioration in turn led to banks stopping their practice of giving loans to each other. This 'Liquidity Concern' in turn made a bad situation worse. In order to prevent this, central banks around the world started to provide funds for banks to ease the situation, however by now this was too little too late. By September 2008 everything began to crash as several gigantic financial institutions filed for bankruptcy. This had a domino effect on the entire global economy which by now had been called the "Global Financial Crisis". On October $3^{\text {rd }}$ President Bush, in a measure to recover the economy, signed a seven hundredbillion-dollar stimulus bill into law. This however was not enough to ease the panic that by now had caused the economic decline of almost all developed nations of the world. In the week following the bill the Dow Jones index declined by $22 \%$, the worst week in its 118 years history. By the end of 2008, the Dow Jones had lost $34 \%$ of its value in the start of the year (BBC News, 2008).

The economic conditions that ensued had a tremendous impact on the price of oil. The price of oil which had reached an all-time high of \$147 in summer 2008 began to decline even before the perceived start of the crisis in September, after that date however, the decline became more rapid. This is apparent in the graph shown below:

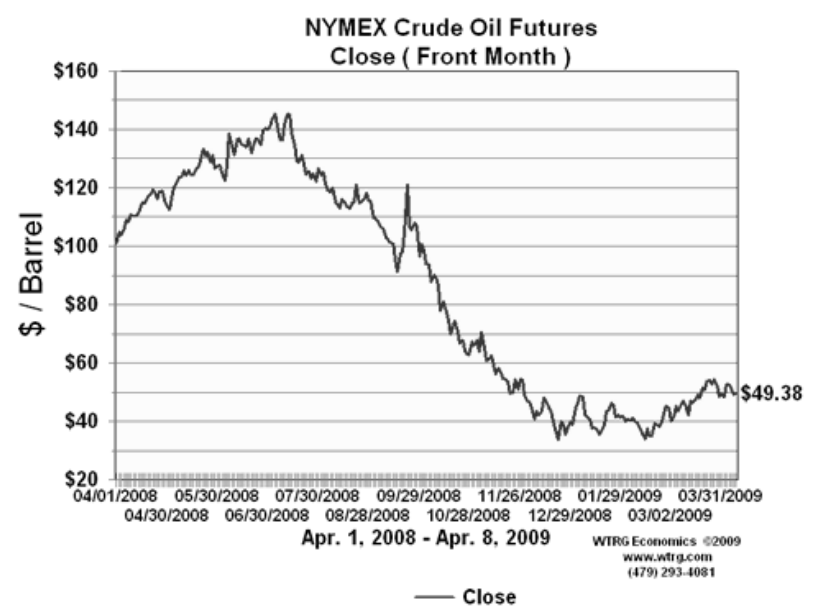

Fig. 6. Crude Oil Prices after the Financial Crisis Source: WRTG Economics using data from NYMEX

As indicated earlier, even before the perceived start of the crisis in September 2008, the price of oil started to decline. The main reason for this was a decline in the demand for oil, as 
economic growth had started to slow down. As can be seen from the graph below, the decline in prices took place after a several months delay from the drop in demand. Analysts believed at the time that the global economy was starting to slow down and that the demand for oil was diminishing, however many inverstors and market analysts still believed that the demand for oil would still remain robust and that future prices would be high, this kept up the price of oil, until several months later when the reality started to be discovered (The Rise and Fall in Oil Prices, 2008).

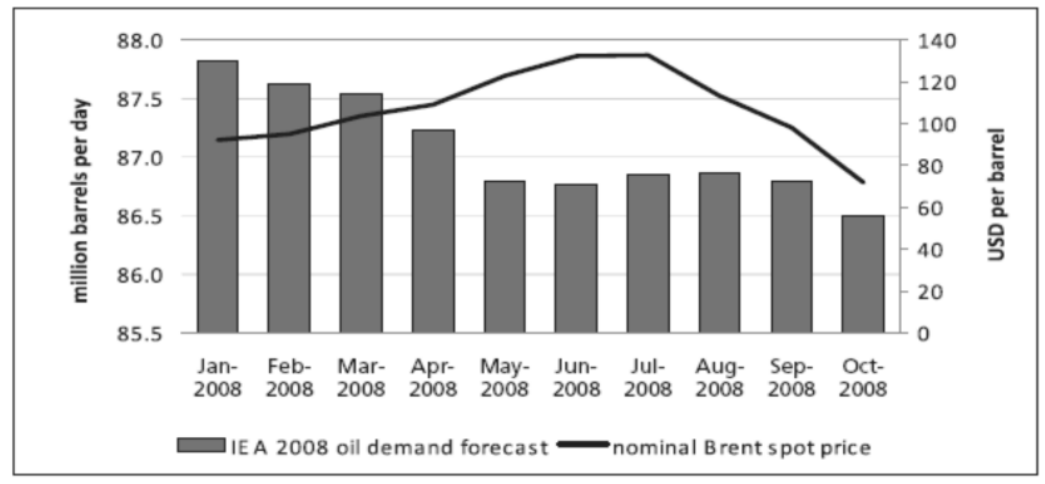

Source: Monthly Oil Market Reports, International Energy Agency

Fig. 7. Oil Prices vs. Oil Demand

The economic crisis has had a devastating effect on the global economy.

Moreover. the economic crisis devastated the industrial sector. The ISM manufacturing index declined to 35.8 in March 2008 compared to an index of near 50 for most of summer 2008.

Table 1. Economic Growth Rates for 2008

\begin{tabular}{|l|l|l|l|l|l|l|l|}
\hline & World & OECD & USA & Japan & Europe & China & India \\
\hline 2008 & 3.1 & 0.9 & 1.1 & -0.7 & 0.8 & 9.0 & 6.6 \\
\hline \multicolumn{7}{|c|}{ Source: Monthly Oil Market Report, OPEC, March 2009 }
\end{tabular}

The economic crisis also resulted in the decline of oil demand. The demand for oil declined by $0.3 \mathrm{mb} / \mathrm{d}$ in 2008, while OPEC said that the global demand would decline by $1 \mathrm{mb} / \mathrm{d}$ in 2009, with the demand growth of all countries except China and the Middle East being negative. OPEC announced that the demand by OECD countries would decline by $1.3 \mathrm{mb} / \mathrm{d}$ while the demand by non OECD countries would increase by $0.3 \mathrm{mb} / \mathrm{d}$, totaling in a decline of $1 \mathrm{mb} / \mathrm{d}$. As a result OPEC decided in its $151^{\text {st }}$ meeting in December 2008 to cut its oil production by $4.2 \mathrm{mb} / \mathrm{d}$ from its September output rate, however this measure had little effect (Koyama, 2009. Also, the Energy Information Administration (EIA) which publishes official US government energy statistics, predicted in its March 2009 Short Term Energy Outlook Report announced there would be a decline of $2.4 \mathrm{mb} / \mathrm{d}$ In 2009. The IEA also estimated that the world's gross domestic product would shrink by 1.4 percent in 2009 (Smith, 2009).

The global economic crisis of 2008 temporarily eased the tight market condition of the oil market, with concerns regarding supply before the crisis changing to concerns about the demand. Not only did the decrease in demand decreased prices directly, but also the decrease in demand has completely changed the speculative activities that were driving up prices.

Unlike before, investors now saw the oil market as volatile, without a clear future of when prices would go back up, resulting in less dealings in the oil market due to speculative 
behaviour. Other than uncertain and grim expectations about the future of oil, another reason that diminished trading was the lack of liquidity. With the financial system crumbling and very little lending going on, investment rates were at all time lows, with many investors sticking with their capital instead of investing due to the uncertain future of the global economy. Also the spare capacity that was discussed in section 2.3 had now increased due to cut backs in OPEC's oil production. In effect the same factors discussed in section 3, which were driving up prices, were now decreasing prices.

\section{US Economic Recovery and the Future of Oil Prices}

Although the global financial led to severely lowered oil prices in 2008, however this was a short lived decline in oil prices, with the price of oil beginning to start its rise in 2009 as the US and global economy slowly began to recover.

While the price oil today is a relatively modest 77 dollar however this section argues that the price of oil will gradually rise in the future. The main reason behind this thesis is that the fundamentals behind the high price of oil are still present today. This is especially true in nonOECD countries like China and India, which are also responsible for the surge in oil demanded in the new century. At the same time the supply of oil will be dependent upon a large investment in the oil industry prior to when the oil demand rises again. Some of the most important reasons behind the thinking that the price of oil will go up again are as follows:

\section{Recovery of the US Economy}

The 2008 financial crisis was the biggest American economic crisis since the great depression. Nevertheless the US economy slowly started to recover in 2009, finally reaching its pre-crisis GDP levels in 2011. Therefore three years after the disaster 2008, the US economy had recovered lost ground and since then has enjoyed a cumulative GDP growth of 14.7 percent (Manibog and Foley, 2017).

Although the US economy is burdened by the increasing federal debt, the unemployment rate and GDP growth have improved in 2017 compared to previous years (Sadowski, 2017).

\section{Economic Growth of non OECD Countries}

Although the global economic crisis has devastated the world economy, however countries like China and India as well as countries in the Middle East, which as indicated earlier are the main sources for the increased demand in oil, are still enjoying a positive GDP growth. For example China's GDP growth is was 6.9 percent in 2017 (Reuters, 2018). Furthermore the IMF predicts that the Chinese economy will grow by 6.6 percent in 2018 (Huanxin, 2018).

Also India's GDP grew by 6.72 percent in 2017 and is expected to further rise by 7.37 percent in 2018 (Statistica, 2018). Also the IMF predicts the global economy to grow by 3.9 percent in both 2018 and 2019 (Huanxin, 2018).

\section{Population Increase}

The world's population is expected to increase by $1 \%$ annually. If this trend continues the world population would reach 8.2 billion in 2030, which is a more than 1.7 billion increase in people from 2006 (World Oil Outlook, 2008). 94\% of this growth is expected to occur in developing countries. Also data from the United Nation's Department of Economic and Social Affairs shows that a populations shift from rural areas to urban areas is expected in the future.

It is expected that by $2030,59 \%$ of the world population will be living in urban areas, compared to $48 \%$ in 2006 (Ibid). This population increase will have an important effect on energy demand, as the new urban population will need access to modern energy services, 
higher car ownership and subsequently higher demand for fuel will result, as well as the need for the extension in public transportation services.

The transportation sector will play an important role in oil demand growth in the future.

Currently, four billion people of the world live in developing countries with an average of less than one car per twenty people. With the expected economic development of these countries in the future, car ownership will expand and as a result fuel consumption will also increase.

\section{Limited Supplies and Lack of Investment}

OPEC estimates that to keep up oil supplies with oil demand in the future, an estimated $\$ 2.8$ trillion dollars is need up to $2030.58 \%$ of this figure is related to the investment needed in non OECD countries (Ibid). The global economic crisis however has severely limited investment in the oil sector. While this situation is slowly changing as the global economy is recovering, however the years gone without investment will heighten problems in the future, where more investment will be needed and supply can only meet demand with a delay, due to the lack of investment during the economic crisis. This is a similar situation to what was explained in the 80s and 90s, where low oil prices resulted in a lack of investment which ultimately curtailed the amount of oil that could be supplied following the turn of the new century. Another important issue regarding oil supply is the limited and finite resources available. Some reports like OPEC's "World Oil Outlook" stress that if needed investment is injected into the oil industry in a consisted manner, then the challenges of resource limitations can be met. Other important institutions like the IEA however, believe that in order to keep up oil supply in the future, production from non OPEC countries must be increased, however oil projects in many of these countries comes at a very high cost, also other non-conventional liquid production methods are very expensive. This coupled with the political uncertainties in many of these areas, plus the prediction that many oil rich countries will move towards "resource nationalism" in which foreign investors have less access to potential sites, make the IEA's assessment grimmer regarding the future potential for growth in oil supply (Annual Energy Outlook, 2009).

\section{Discouraging Growth in the Renewable Energy Industry}

There are still high hopes for renewable energies like nuclear, wind and solar, however these industries still have a long way to go before they can provide a major share of the world's energy resources. These industries are still in need of substantial investment, a prospect which has diminished with the current lack of liquidity and investment. Even if these industries develop faster than what is anticipated, it will still take time for them to enter their products into consumer markets in an economically viable manner. Plus an extra period of time is needed for the wide spread adoption of these products. That is why almost all energy outlooks predict that Oil, Natural Gas and Coal will still make up the major share of the world's energy consumption in the future (World Oil Outlook, 2008).

For the reasons listed above, it is predicted that the price of oil will increase gradually until the year 2050. The IEA 2018 Annual Energy Outlook report predicts that in 2017 dollars, the price of oil reaches $\$ 229$ per barrel by 2050 in a "High Oil Price case", compared with $\$ 114$ per barrel in the Reference case (US Energy Information Administration, 2018).

\section{Conclusions}

The Price of oil has steadily increased with the start of the twenty first century. 
This has been due to many factors, the most important of which has been the fundamental demand and supply of the market, with demand increasing each year due to global economic growth particularly in countries like China, India, Brazil and the countries of the Middle East.

At the same time supply of oil could not be increased substantially to meet these needs because of the lack of investment in the 80 s and 90 s. When the equilibrium between demand and supply started to change, the change in price was substantial. This is due to the fact that both oil supply and oil demand, are inelastic, meaning there responsiveness to price change is low, thus a significant price change would occur in order to reach a new equilibrium. Another important factor in rising oil prices was the 'expectations' factor, meaning that analysts and investors expected that the price of oil would increase, this led to speculative behavior which led to further increases in oil prices. Thus a vicious cycle had taken hold in which speculation would lead to price increases, after which price increases would further lead into more speculation. Some analysts however have raised doubts about the share of this kind of behavior in raising oil prices.

By summer 2008, the US financial crisis led to the slow down of the global economy and subsequently oil demand shrunk, after the financial crisis of September 2008 however, this decline took on a new momentum, bringing oil prices to under 35 dollars. While the global economic crisis seriously curtailed oil demand, however this was a short term decline. The US economy slowly began to recover starting in 2009, leading to recoveries elsewhere around the world. This brought oil prices to over 70 dollars today. Futhermore it can be expected that since the fundamental reasons behind rising oil prices, being demand and supply, are still valid, thus in the long run oil prices will increase to pre-crisis levels. Also many oil fields in which production cost could be kept to a minimum have been depleted, leaving more expensive oil fields as well non-conventional oil production methods which are even more expensive. This is why most oil outlooks stress that the price of oil will steadily increase, with the Annual Energy Outlook of 2018 predicting that the price of oil will gradually rise until it reaches 114 to 229 dollars by 2050 (US Energy Information Administration, 2018).

\section{REFERENCES}

1. BBC News (2008). Record stock market falls in 2008, December 31, accessed at: http://news.bbc.co.uk/2/hi/business/7805644.stm

2. British Petroleum (2018). Oil Production: World oil production grew by only 0.4 million b/d in 2016, the slowest growth since 2013. accessed at: https://www.bp.com/en/global/corporate/energy-economics/statistical-review-ofworld-energy/oil/oil-production.html

3. CNN (2009). Oil slips below $\$ 35$. February $18^{\text {th }}$, accessed at: http://money.cnn.com/2009/02/18/markets/oil.reut/index.htm

4. Huanxin, Z. (2018). IMF raises global growth for 2018, 2019, China Daily, January 22.

5. Interim Report on Crude Oil (2008). Interagency Task Force on Commodity Markets (ITF), United States Government, July.

6. International Energy Agency (2007). World Energy Outlook 2007.

7. Kebede, R. (2008). Oil hits record above $\$ 147$. Reuters. July $11^{\text {th }}$, accessed at: Koyama, K. (2009). Prospects for International Oil Markets and Crude Prices in 2009. Institute of Energy Economics Japan, IEEJ.

8. Manibog, C., Foley, S. (2017). The Long and Winding Road to Economic Recovery. Financial Times.

9. MSNBC (2007). Will subprime mess ripple through economy? $13^{\text {th }}$ March, accessed at: http://www.msnbc.msn.com/id/17584725 
10. Peak Oil Barrel (2018). OPEC Charts, accessed at: http://peakoilbarrel.com/opeccrude-oil-production-charts/

11. Poundsterlinglive (2018). US Dollar to Euro Spot Exchange Rates for 2001 from the Bank of England. accessed at: https://www.poundsterlinglive.com/bank-of-englandspot/historical-spot-exchange-rates/usd/USD-to-EUR-2001

12. RealtyTrac (2008). U.S. Forclosure Activitiy Increases 75 Percent in 2007. January 29 , accessed

at: http://www.realtytrac.com/ContentManagement/pressrelease.aspx?ChannelID=9\&It emID $=3988 \&$ accnt $=64847$

13. Reuters (2018). China's Economic Growth Last Year Was Even Better Than Expected, Fortune. Accessed at: http://www.reuters.com/article/topNews/idUST14048520080711

14. Sadowski, C. (2017). Finally: Signs of a Real Economic Recovery for the US. New York Post.

15. Smith, G. (2009). IEA Cuts Oil Demand Forecast to Lowest in Five Years. Bloomberg Press.

16. Statistica (2018). India: Real gross domestic product (GDP) growth rate from 2012 to 2022 (compared to the previous year), accessed at: https://www.statista.com/statistics/263617/gross-domestic-product-gdp-growthrate-in-india/

17. The rise and fall in oil prices: analysis of fundamental and financial drivers (2008). Global Energy Team, Cabinet Office, UK Government.

18. US Energy Information Administration (2018). Annual Energy Outlook.

19. US Energy Information Administration (2018). What Drives Crude Oil Prices?: An analysis of 7 factors that influence oil markets, with chart data updated monthly and quarterly.

20. World Oil Outlook (2008). Organization for Petroleum Exporting Countries (OPEC).

\section{Article history: \\ Received 18 February 2018 \\ Accepted 10 June 2018}

